\title{
Peran Permainan Pohon Angka dalam menstimulasi Pengetahuan Visual Mengenal Angka 1-10 pada Anak Usia 4-5 Tahun
}

\section{Muhammad Lukman Haris Firmansah}

Program Studi Pendidikan Anak Usia Dini, Universitas PGRI Ronggolawe @ firmantp2013@gmail.com

\begin{tabular}{l|l}
\hline Kata Kunci: & Abstrak \\
\hline $\begin{array}{l}\text { Pohon Angka, } \\
\text { Stimulasi, }\end{array}$ & $\begin{array}{l}\text { Pertumbuhan dan perkembangan anak distimulasi dengan berbagai macam jenis } \\
\text { permainan. Pohon angka merupakan salah satu permainan yang sering digunakan dalam } \\
\text { pembelajaran. Minim pengetahuan fasilitator mengenai keunggulan dan kelemahannya, } \\
\text { sehingga pada kesempatan ini peneliti melakukan penelitian mengenai pohon angka. } \\
\text { Hasil dari penelitian ini diperoleh dengan cara wawancara dan observasi, selanjutnya } \\
\text { dilakukan analisis menggunakan metode trianggulasi data untuk mendapatkan data yang } \\
\text { valid. Hasil instrumen pengamatan yakni 72\% anak dapat mengambil angka, 82\% anak } \\
\text { dapat menempelkan angka, 85\% anak dapat menunjukkan angka. Stimulus yang } \\
\text { ciptakan melalui permainan pohon angka yakni melihat lambang angka secara berulang- } \\
\text { ulang dimulai proses mengambil, menempelkan, menunjukkan dan menyebutkan angka. }\end{array}$ \\
\hline $\begin{array}{l}\text { Keywords: } \\
\text { Trees, }\end{array}$ & $\begin{array}{l}\text { Abstract } \\
\text { Chimulation, } \\
\text { Children }\end{array}$ \\
$\begin{array}{l}\text { is one game that is often used in learning. Lack of facilitator's knowledge of their } \\
\text { strengths and weaknesses, so that on this occasion researchers conducted research on } \\
\text { numerical trees. The results of this study were obtained by means of interviews and } \\
\text { observations, then analyzed using the data triangulation method to obtain valid data. The } \\
\text { result of the observation instrument is that 72\% of children can take numbers, } 82 \% \text { of } \\
\text { children can attach numbers, 85\% of children can show numbers. Stimulus, which is } \\
\text { created through numerical tree play that is to see the symbol of numbers repeatedly } \\
\text { begins the process of taking, pasting, showing and mentioning numbers. }\end{array}$ \\
\hline
\end{tabular}

\section{A. Pendahuluan}

Pendidikan anak usia merupakan pondasi awal dalam mengembangkan pertumbuhan dan perkembangan anak. Pertumbuhan dan perkembangan anak sendiri telah diatur dalam peraturan menteri Pendidikan no 146 tahun 2014 yang sering disebut standar pencapaian perkembangan anak. Pada lampiran peraturan menteri tersebut juga memuat indikator pencapaian perkembangan anak meliputi aspek moral dan agama, fisik-motorik, kognitif, sosial-emosional, bahasa dan seni. Salah satu indikator dalam pencapaian perkembangan anak yakni menghubungkan benda-benda konkret dengan lambang bilangan 1-10.

Mengenal lambang bilangan atau simbol angka merupakan hal yang pertama perlu dipelajari sebelum melangkah atau mempelajari pada operasi hitung. Pembelajaran anak usia dini memberikan perhatian yang cukup pada kemampuan mengenal angka. Guru menggunakan berbagai macam media dan permainan untuk mengenalkan angka $1-10$. Tentunya media dan permainan tersebut tidak terlepas dari paradigma pembelajaran PAUD yakni bermain sambil belajar. Ada berbagai permainan yang dapat dimainkan anak dalam mengenal angka salah satunya yakni pohon angka.

Pohon angka merupakan salah permainan edukatif yang memang dirancang secara khusus dengan tujuan tertentu. Permainan edukatif merupakan permainan yang memiliki kemampuan memfasilitasi berbagai aspek perkembangan anak. Pada umumnya pohon angka dirancang secara 
khusus untuk mengenalkan angka tanpa mentiadakan aspek perkembangan lainnya seperti fisikmotorik, moral-agama, sosial-emosional, bahasa dan seni. Permainan pohon angka dibuat dari bahan bekas seperti kardus atau lainnya. Selanjutnya dari bahan bekas tersebut digunting atau dibentuk menyesuaikan dengan pohon yang ingin ditampilkan. Dari bentuk guntingan pohon tersebut kemudian diberi warna agar menarik. Pada gambar daun itulah angka-angka tersebut akan ditempelkan atau disusun. Konsep permainan tersebut sudah berkembang di pembelajaran PAUD. Hal tersebut merupakan inovasi yang dilakukan oleh para pendidik dalam mengembangkan media pembelajaran.

Pemilihan aktivitas bermain merupakan hal yang cukup penting sebelum menggunakan permainan. Salah penyebab permainan tersebut tidak interaktif yakni minimnya aktivitas bermain yang diberikan. Namun ada beberapa media yang dapat interaktif meskipun minim aktivitas yang direncanakan oleh fasilitator.

Dilingkungan keluarga, orang tua sering kali memberikan permainan tanpa mengetahui manfaat bagi anaknya. Permainan masih cenderung berparadigma bermain, sehingga kebutuhan masa depan anak tidak hanya bermain namun belajar sehingga pengetahuan yang dibentuk masih minim belum dioptimalkan. Beberapa fasilitator juga masih minim pengetahuan mengapa permainan tersebut digunakan. Hal tersebut berdampak pada kegiatan atau aktivitas anak, sebab beberapa permaianan dipilih untuk lebih mengaktifkan model dan metode pembelajaran tertentu. Selain itu, bagaimana menggunakan permainan atau prosedur bermain menggunakan permainan belum sesuai dengan karakteristik atau kelebihan yang dimiliki oleh permainan tersebut.

Penggunaan permainan hendaknya mengikuti konsep belajar. Menurut Spears (Dalam Suryabrata, (2004:231) menjelaskan sebagik-baiknya belajar adalah dengan mengalami, dan dalam mengalami itu si pelajar mempergunakan panca inderanya. Jenis permainan yang dipilih sangat berhubungan dengan pengalaman yang hasilkan nantinya. Belajar menggunakan sebuah permaianan menjadikan pembelajaran tersebut bermakna.

Menurut Mursid (2015:29) Bagi anak-anak, bermain merupakan kebutuhan yang sangat penting dan berpengaruh pada aspek fisik dan psikologi sehingga berpengaruh jug pada tinggi rendahnya pestasi anak-anak. Bermain dan permainan merupakan hal yang terpisahkan dalam diri anak. Melalui bermain anak mendapatkan manfaat secara fisik, kognitif dsb. Sehingga dunia anak ialah dunia bermain.

Berbagai permainan memiliki tujuan dan manfaat tertentu bagi penggunanya. Beberapa pengguna bahkan belum mengetahui manfaat setelah menggunakan permainan. Hal tersebut berdampak pada kepribadian dan pengetahuan anak secara berkelanjutan, sebab stimulasistimulasi yang telah diberikan oleh permainan yang sifatnya tidak edukatif akan merusak kepribadian dan pengetahuan anak. Sebab banyak anak menjadi malas atau bicara kotor setelah bermain menggunakan permainan tertentu. Berkaitan dengan sangat pentingnya permainan sebagai alat stimulasi dalam membentuk kepribadian dan pengetahuan anak sejak dini.

Permainan tentu tidak terlepas dari interaksi yang dihasilkannya. Kesalahan dalam memilih informasi karena alasan belum memahami atau kesalahan dalam menggunakan permainan sering terjadi. Atas dasar apa permainan tersebut dipilih, hal tersebut merupakan hal yang cukup penting. Ada berbagai permainan telah dipilih pada pembelajaran tertentu dengan tujuan untuk mengaktifkan anak. Bagaimana peran permainan tersebut dalam mengaktifkan aktivitas dan mentransfer informasi masih minim penelitian dalam hal tersebut. Sehingga pada kesempatan ini peneliti ingin meneliti "Peran Permainan Pohon Angka dalam menstimulasi Pengetahuan Visual Mengenal Angka 1-10 pada Anak Usia 4-5. 
Berdasarkan hal diatas dapat diidentifikasi masalah sebagai berikut 1) pengetahuan simbol atau angka merupakan pengetahuan dasar yang penting untuk pahami oleh anak. 2) dasar pemilihan permainan untuk anak yang belum dipahami alasannya oleh fasilitator, 3) minimnya pengetahuan fasilitator mengenai tujuan penggunaan pohon angka sebagai alat bermain anak. 3) minimnya pengetahuan fasilitator dalam menggunakan atau prosedur penggunaan pohon angka, 4) belum memahami jenis stimulasi yang dihasilkan oleh sebuah permainan. Sehubungan dengan identifikasi masalah tersebut dapat dirumuskan permasalahan sebagai berikut yakni 1) Bagaimana permainan pohon angka dalam mestimulasi pengetahuan visual mengenal angka 1-10?.

Adapun tujuan dari penelitian ini yakni untuk mengetahui proses stimulasi menggunakan permainan pohon angka dalam menstimulasi pengetahuan visual mengenal angka. Ruang lingkup pada penelitian ini yakni memahami stimulus yang diciptakan pohon angka, pengetahuan visual mengenal angka 1-10, serta anak usia 4-5 tahun. Adapun manfaat dari penelitian ini yakni bagi fasilitator dapat menggunakan permainan pohon angka secara efektif. Bagi orang tua dapat digunakan sebagai dasar pemilihan media lainnya untuk menstimulasi perkembangan anak.

\section{B. Metodologi}

Penelitian ini merupakan jenis penelitian kualitatif yang betujuan untuk mengidentifikasi, memahami dan menganalisis sebuah stimulasi yang ditawarkan oleh permainan pohon angka. Penelitian kualitatif deskriptif pada penelitian ini bertujuan untuk mengetahui gejala-gejala yang diciptakan oleh sebuah permainan yakni pohon angka kemudian dideskripsikan dalam bentuk kata-kata. Dari-dari hal tersebut nantinya digunakan sebagai upaya menyimpulkan terhadap stimulasi-stimulasi yang diberikan.

Subjek penelitian pada penelitian ini yakni anak usia $4-5$ tahun. Pemilihan subjek penelitian didasari pada indikator pencapaian perkembangan anak yang dituangkan dalam Permendikbud no 146 Tahun 2014. Sedangkan pemilihan lokasi penelitian dengan mempertimbangkan lembaga yang sering menggunakan alat permainan edukatif dalam pembelajarannya. Adapun lokasi penelitian berada di TK PGRI Plumpang-Tuban. Kondisi pembelajaran yang diamati ketika menggunakan permainan pohon angka.

Instrumen yang digunakan dalam penelitian ini berupa instrumen wawancara langsung secara tertutup artinya butir-butir pertanyaan telah dibuat terlebih dahulu selanjutnya ditanyakan secara langsung kepada subjek penelitian. Instrumen wawancara pada penelitian ini digunakan sebagai data primer untuk menyimpulkan hasil penelitian. Sedangkan instrumen pengamatan digunakan secara sebagai data sekunder yakni data pendukung penelitian dalam menyimpulkan. Adapun butir-butir pertanyaan yang ditanyakan pada penelitian ini yakni 1) Adik bermain apa? 2) angkanya diapakan? /bagaimana cara bermaiannya ?/apa yang telah adik mainnkan? 3) susunan angka ditempelkan atau dipasangkan pada pohon angka harus seperti apa ? 4) Adik dapat menunjukkan angka 1/2/3/4/5/6/7/8/9/10 ?. Sedangkan instrumen pengamatan berisi item pengamatan seperti beriku : 1)Bagaimana anak mengambil angka ?, 2 )Bagaimana anak bermain/menempelkan angka?, 3)Bagaimana anak dapat menunjukkan angka?. Instrumen pengamatan berfokus pada proses bermain menggunakan permainan pohon angka sedangkan instrumen wawancara fokus pada identifikasi pengetahuan yang terbentuk. Instrumen pengamatan mengginakan skala likerd yakni sangat baik, baik, cukup, kurang, sangat kurang. Dari skala tersebut natinya dikonversi kedalam bentuk data ordinal yang digunakan untuk menyajikan data dalam bentuk diagram batang.

Informan yang dimintai pendapat yakni anak yang merupakan subjek melakukan kegiatan bermain. Dari sumber inilah informasi-informasi yang didapatkan akan disajikan bersamaan 
dengan data pengamatan atau observasi sebelum disajikan ke metode trianggulasi data. Informasiinformasi tersebut merupakan pengalaman belajar yang terbentuk.

Teknik analisa data yang digunakan pada penelitian ini menggunakan teknik trianggulasi data yakni dengan cara membandingkan data primer dan sekunder. Data primer merupakan data yang didapat dari hasil wawancara sedangkan data sekunder dari hasil pengamatan. Menggunakan teknik trianggulasi data diharapkan agar data tersebut dan memiliki konsitensi dalam hasil dari kedua data tersebut.

\section{Hasil Dan Pembahasan}

Data diperoleh pada saat proses pembelajaran berlangsung. Data yang daimbil dan digunakan pada penelitian ini yakni data hasil wawancara dan data hasil pengamatan. Dari hasil wawancara yang dilakukan di lembaga dengan responden sejumlah 10 anak didapatkan hasil rekapitulasi sebagai berikut.

Tabel 1 Hasil Wawancara

\begin{tabular}{|c|c|c|c|}
\hline 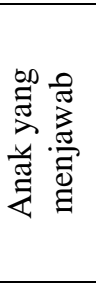 & $\begin{array}{l}\text { 1) Adik } \\
\text { bermain } \\
\text { apa? }\end{array}$ & $\begin{array}{l}\text { 2) Angkanya diapakan? /bagaimana cara } \\
\text { bermaiannya? / apa yang telah adik } \\
\text { mainkan?atau dipasangkan pada } \\
\text { pohon angka harus seperti apa ? 4) } \\
\text { Adik dapat menunjukkan angka } \\
1 / 2 / 3 / 4 / 5 / 6 / 7 / 8 / 9 / 10 ?\end{array}$ & $\begin{array}{l}\text { 3) Susunan angka ditempel } \\
\text { temannya tadi /Angka itu } \\
\text { dimulai angka berapa }\end{array}$ \\
\hline 1 & Pohon & Ditempel, pohon angka, ini angka 3 & Satu \\
\hline 2 & Pohon Angka & Ditaruh pohon, pohon, ini angka 4 & Satu, Dua, \\
\hline 3 & Pohon Angka & Ditempelin, pohon angka, ini angka 5 & Satu, Dua, tiga \\
\hline 4 & Angka & Ditaruh pohon, pohon, ini angka 6 & Satu, Dua, Tiga, empat \\
\hline 5 & Pohon Angka & Ditempel, pohon angka, ini angka 7 & $\begin{array}{l}\text { Satu, Dua, Tiga, Empat, dan } \\
\text { Lima }\end{array}$ \\
\hline 6 & Pohon Angka & Ditempel, pohon angka, ini angka 8 & $\begin{array}{l}\text { Satu, Dua, Tiga, Empat, Lima, } \\
\text { Enam }\end{array}$ \\
\hline 7 & Pohon Angka & $\begin{array}{l}\text { Ditaruh pohon daun, pohon angka, ini } \\
\text { angka } 9\end{array}$ & $\begin{array}{l}\text { Satu, Dua, Tiga, Empat, Lima, } \\
\text { Enam, Tujuh }\end{array}$ \\
\hline 8 & Pohon Angka & $\begin{array}{l}\text { Ditempelkan daun, pohon angka, ini } \\
\text { angka } 10\end{array}$ & $\begin{array}{l}\text { Satu, Dua, Tiga, Empat, Lima, } \\
\text { Enam, Tujuh, Delapan }\end{array}$ \\
\hline 9 & Angka & Ditempelkan, pohon angka, ini angka 1 & $\begin{array}{l}\text { Satu, Dua, Tiga, Empat, Lima, } \\
\text { Enam, Tujuh, Delapan, Sembilan }\end{array}$ \\
\hline 10 & Pohon Angka & Ditempel, pohon angka, ini angka 2 & $\begin{array}{l}\text { Satu, Dua, Tiga, Empat, Lima, } \\
\text { Enam, Tujuh, Delapan, Sembilan, } \\
\text { Sepuluh }\end{array}$ \\
\hline
\end{tabular}

Dari data tersebut menunjukkan bahwa pada dasarnya anak mengetahui apa yang dimainkan. Pada tahap tahap awal anak sudah memperoleh stimulasi visual berupa pohon angka sehingga sebagian mereka bisa menjaab ketika ditanya. Tahap selanjutnya pada saat cara bermain dan menunjukkan angka, anak memahami bahwa mereka harus mengambil angka terkecil kemudian ditempel pada pohon angka. Pada tahap ini terjadi stimulasi mengambil angka terkecil dan menentukan posisi angka terkecil tersebut. Pada saat anak mengambil angka terkecil dalamnya terdapat berbagai macam angka anak harus bisa terkecil yakni 1, sehingga terjadi proses memilih dan mengingat lambang angka terkecil kemudian menaruhnya. Kemudan pada saat menempelkan sudah secara sadar baha angka terkecil terletak disebelah kiri hal tersebut 
menunjukkan bahwa terjaadi stimulasi ingatan uruatan bilangan. Pada kegiatan diarahkan untuk mengucapkan sebuah angka terjadi proses mengingat atau reacaling informasi. Pada tahap terakhir anak mencoba menyebutkan susunan yang telah disusun temannya hal ini untuk mengetahui urutan angka. Pada tahap ini terjadi stimulasi ingatan mengeani urutan angka. Selain menggunakan instrumen wawancara peneliti menggunakan instrumen pengamatan. Adapun hasil pengamatan sebagai berikut.

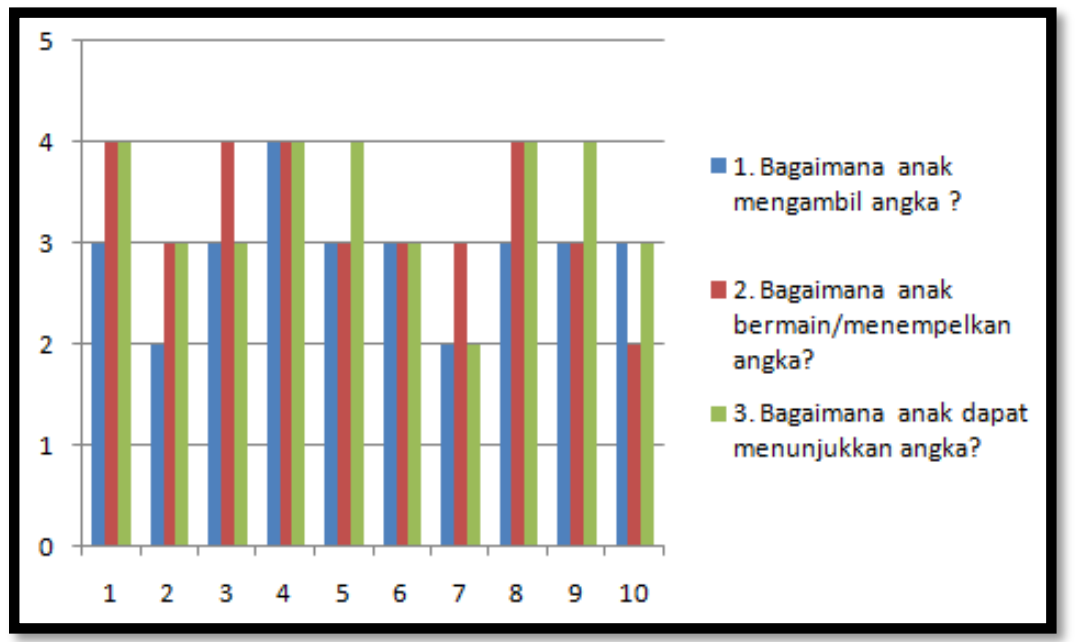

Gambar 1 Hasil Pengamatan

Data hasil pengamatan pada indikator mengambil angka menunjukkan bahwa proses anak mengambil angka cenderung baik, meskipun ada 2 anak yang mendapatkan nilai kurang. Pada indikator kedua menunjukkan bahwa bermain/menempelkan angka anak cukup baik. Dan indikator ketiga menjelaskan bahwa anak dapat menunjukkan angka dengan rata-rata penilaian baik. Dari kedua data tersebut selanjutnya dilakukan trianggulasi data yakni membandingkan data.

Beberapa data yang diperoleh pada penelitian merupakan hasil dari data wawancara dan observasi/pengamatan. Wawancara dilakukan pada saat melakukan aktivitas mengambil, menempelkan dan menunjukkan angka. Sedangkan data hasil observasi diperoleh dengan bantuan guru ketika anak melakukan aktivitas tersebut. Hasil dari data tersebut kemudian dibandingkan. Adapun hasil perbandingan kedua data tersebut sebagai berikut.

Tabel 2 Hasil Trianggulasi Data

\begin{tabular}{|c|c|c|c|}
\hline $\begin{array}{c}\text { Butir } \\
\text { pertanyaan/Jenis } \\
\text { Data }\end{array}$ & wawancara & Pengamatan & Kesimpulan \\
\hline $\begin{array}{l}\text { Pertanyaan/ butir } \\
\text { pengamatan ke-1 }\end{array}$ & 1) Adik bermain apa? Pohon Angka & $\begin{array}{l}\text { 1. Bagaimana anak mengambil angka ? } \\
\text { rata-rata anak mendapatkan nilai Baik }\end{array}$ & $\begin{array}{l}\text { Anak sudah mengetahui dengan mudah } \\
\text { jenis permainan dibuktikan ketika ia } \\
\text { bermain yakni mengambil anglka }\end{array}$ \\
\hline $\begin{array}{l}\text { Pertanyaan/ butir } \\
\text { pengamatan ke-2 }\end{array}$ & $\begin{array}{l}\text { 2) Angkanya diapalkan? /bagaimana cara } \\
\text { bermaiannya ?/apa yang telah adik } \\
\text { mainkan?atav dipasangkan pada pohon angka } \\
\text { harns seperti apa ? 4) Adik dapat menunjulkkan } \\
\text { angka } 1 / 2 / 3 / 4 / 5 / 6 / 7 / 8 / 9 / 10 \text { ? Ditempel, pohon } \\
\text { angka, ini angka 3 }\end{array}$ & $\begin{array}{l}\text { 2. Bagaimana anak } \\
\text { bermain/menempelkan angka? rata-rata } \\
\text { anak mendapatkan nilai baik }\end{array}$ & $\begin{array}{l}\text { Anak memahami bagaimana meletakksan } \\
\text { angka pada pohon tersebut sesvai unvtan }\end{array}$ \\
\hline $\begin{array}{l}\text { Pertanyaan/ butir } \\
\text { pengamatan ke-3 }\end{array}$ & $\begin{array}{l}\text { 3) susunan angka ditempel temannya tadi } \\
\text { Angka itu dimvlai angka berapa ? Satu }\end{array}$ & $\begin{array}{l}\text { 3. Bagaimana anak dapat menunjuktkan } \\
\text { angka? rata-rata anak mendapathan nilai } \\
\text { baik }\end{array}$ & $\begin{array}{l}\text { Anak dapat menunjukkkan dan } \\
\text { menyebutkan angha yang telah ditempel } \\
\text { dipohon tersebut }\end{array}$ \\
\hline
\end{tabular}


Dari hasil trianggulasi data menunjukkan bahwa ada konsistensi antara data hasil wawancara dengan data hasil pengamatan. Hal tersebut menunjukkan bahwa ada nilai kevalidan dalam data tersebut.

\section{Kesimpulan}

Berdasarkan hasil wawancara dan pengamatan yang dilakukan pada permainan pohon angka disimpulkan sebagai berikut.

1. Stimulasi visual yang terjadi ketika anak melihat bentuk permainan yakni permainan pohon angka, mengambil angka terkecil dari berbagai macam angka, meletakkan atau menentukan posisi angka dalam pohon tersebut, kemudian dilanjutkan menyebutkan angka yang telah ditempel temannya dan kemudian menunjukkan. Adpun rincian stimulasi yang terjadi yakni melihat bentuk permainan, melihat konkret permainan yang tertlis lambang angka, menentukan letak angka terkecil, memperhatikan angka yang ditempel temannya, memperhatikan angka yang disebut temannya. Melalui pohon angka anak dapat dirangsang untuk mengingat simbol atau bilangan secara berulang-ulang dan ini merupakan upaya terbentuknya ingatan jangka panjang bagi anak.

2. Suasana pembelajaran semakin aktif setelah menggunakan permainan pohon angka hal tersebut dilihat dari partisipasi anak untuk beermain secara terus-menerus.

3. Hasil penelitian menunjukkan adanya konsistensi antara hasil wawancara dan observasi.

\section{E. Ucapan Terima Kasih}

Peneltian ini dapat terselesaikan tidak lepas dukungan dan bantuan dari berbagai pihak. Peneliti mengucapkan terima kasih kepada keluarga yang selalu memberikan dukungan secar moril dalam menyelesaikan penelitian ini. Kepada pihak lembaga terima kasih atas bantuan dan ijin untuk dijadikan tempat penelitian. Kepada para senior terima kasih atas bimbingan dan arahannya selama ini.

\section{Daftar Pustaka}

Anderson, dkk ( 2001). A Taxonomy for Learning and Teaching and Assesing. New York : Pre Press Company Inc

Arsyad, Azhar (2011). Media pendidikan. Jakarta : Raja Grafindo Persada

Asyhar, R. (2012). Kreatif Mengembangkan Media Pembelajaran. Jakarta :Referensijakarta

Fenrich, P., dkk (1997) Instructional Multimedia Aplication. The United State of America : Hardcourt Brace College Publishers.

Gustafson., dkk (1997) Survey of Instructional Development Models.Washington DC : Eric Publications

Heinich, R., dkk (2002) Instructional Media and Technology for Larning. The United State of America : Conruer Kendell Ville.

Izzaty R. E, dkk (2008) . Perkembangan Peserta Didik. Yogyakarta : Universitas Negeri Yogyakarta Press.

Mursid (2015). Belajar dan Pembelajaran PAUD. Bandung : PT Remaja Rosdakarya Offset

Mustaji, (2013). Media Pembelajaran, Surabaya: Unesa Press.

Subrata, S. (2004). Psikologi Pendidikan. Jakarta : Rajaali Presss 
Sutirna. (2013) Perkembangan dan Pertumbuhan Peserta Didik. Yogyakarta : CV Andi Offset

Sudjana, N. (2005) Metoda Statistika. Bandung : PT Tarsito Bandung

Suyanto S (2005) Dasar-dasar Pendidikan Anak Usia Dini . Yogyakarta : Hikayat Publishing

Suyawan, I., dkk (2013) Pembelajaran Berbasis Kompetensi Mata Pelajaran Matematika (Peminatan) melalui Pendekatan Saintifik. Jakarta : Dirjen Dikmen

Schunk D H. (2012) Learning Theories an educational perpective.United State of America : Pearson Education.Inc 